\begin{tabular}{l} 
JOURNAL OF EMPOWERMENT \\
VOL. 2, No. 2, Desember 2021, h. 276-285 \\
ISSN 2580-0620 (Print) \\
ISSN 2597-9809 (Online) \\
Available Online at https://jurnal.unsur.ac.id/index.php/JE \\
\hline \hline
\end{tabular}

\title{
SOSIALISASI ASAS TUJUAN LEMBAGA KERJASAMA BIPARTIT DAN PENCEGAHAN PERSELISIHAN HUBUNGAN INDUSTRIAL
}

\section{SOCIALIZATION OF THE PRINCIPLES OF THE OBJECTIVES OF BIPARTITE COOPERATION INSTITUTIONS AND PREVENTION OF INDUSTRIAL RELATIONSHIP DISPUTES}

\author{
Ahmad Hunaeni Zulkarnaen \\ Universitas Suryakancana \\ ahmadhzul@gmail.com
}

Masuk: 28 Agustus 2021 Penerimaan: 04 Desember 2021

Publikasi: 31 Desember 2021

\begin{abstract}
ABSTRAK
Lembaga Kerja Sama Bipartit merupakan forum komunikasi dan konsultasi antara pengusaha dengan wakil serikat pekerja/serikat buruh dan/atau wakil pekerja/buruh untuk menciptakan hubungan industrial yang berkeadilan menjaga kelangsungan hidup, pertumbuhan, dan perkembangan perusahaan, termasuk kesejahteraan pekerja/buruh. sehingga dapat mencegah terjadinya perselisihan hubungan industrial, walaupun terjadi perselisihan hubungan industrial dapat selesaikan secara musyawarah (bipartit) tanpa harus melibatkan pihak ketiga, sehingga mogok dan penutupan perusahaan (lockout) tidak perlu digunakan untuk memaksakan kehendak. fungsi hukum LKS Bipartit, adalah: sebagai standard of conduct, sebagai as a tool of social of engeneering, sebagai as a tool of social of control dan sebagai as a facility on human interaction untuk mewujudkan hubungan industrial harmonis (Industrial Peace) yaitu hak dan kewajiban pengusaha serta pekerja/buruh terjamin dan dapat dilaksanakan, mencegah potensi terjadinya perselisihan hubungan industrial dan kalaupun terjadi perselisihan hubungan industrial tidak perlu melibatkan pihak ketiga karena dapat diselesaikan secara musyawarah (Bipartit) secara internal sehingga mogok dan penutupan perusahaan (lock out) tidak perlu digunakan untuk memaksakan kehendak.
\end{abstract}

Kata Kunci : Asas; Bipartit; Industrial; Perselisihan.

\begin{abstract}
The Bipartite Cooperation Institution is a forum for communication and consultation between employers and representatives of trade unions/labor unions and/or representatives of workers/laborers to create fair industrial relations to maintain the survival, growth, and development of the company, including the welfare of workers/labourers. so that it can prevent industrial relations disputes, even though industrial relations disputes can be resolved by deliberation (bipartite) without having to involve third parties, so strikes and company closures (lockout) do not need to be used to impose their will. The legal functions of the Bipartite LKS are: as a standard of conduct, as a tool of social engineering, as a tool of social control and as a facility on human interaction to realize harmonious industrial relations (Industrial Peace), namely rights and obligations. employers and workers/labourers are guaranteed and enforceable, preventing potential industrial relations disputes and even if industrial relations disputes occur, there is no need to involve third parties because they can be resolved internally by deliberation (Bipartite) so strikes and company closures (lock out) do not need to be used to obtrude.
\end{abstract}

Keywords $\quad$ : Principle; Bipartite; Industrial; Dispute. 


\section{A. PENDAHULUAN}

LKS Bipartit, adalah forum komunikasi dan konsultasi mengenai hal-hal yang berkaitan dengan hubungan industrial di satu perusahaan yang anggotanya terdiri dari pengusaha dan serikat pekerja/serikat buruh yang sudah tercatat di instansi yang bertanggung jawab di bidang ketenagakerjaan atau unsur pekeria/buruh (Utami, 2013) (Vide Pasal 1 ayat (1) Peraturan Menteri Tenaga Kerja Dan Transmigrasi Republik Indonesia Nomor Per. 32/Men/XII/2008 Tentang Tata Cara Pembentukan Dan Susunan Keanggotaan Lembaga Kerja Sama Biparti selanjutnya disingkat Permenakertrans RI 32/2008). Serikat pekerja/serikat buruh adalah: "Organisasi yang dibentuk dari, oleh, dan untuk pekerja/buruh baik di perusahaan maupun di luar perusahaan, yang bersifat bebas, terbuka, mandiri, demokratis, dan bertanggung jawab guna memperjuangkan, membela serta melindungi hak dan kepentingan pekerja/buruh serta meningkatkan kesejahteraan pekerja/buruh dan keluarganya (Vide Pasal 1 ayat (17) Undang-Undang Nomor 13 Tahun 2003 tentang Ketenagakerjaan, selanjutnya disingkat UUK)".

Hubungan industrial adalah suatu sistem hubungan yang terbentuk antara para pelaku dalam proses produksi barang dan/atau jasa yang terdiri dari unsur pengusaha, pekerja/buruh, dan pemerintah yang didasarkan pada nilai nilai Pancasila dan Undang Undang Dasar Negara Republik Indonesia Tahun 1945, selanjutnya disingkat UUD 1945 (Vide Pasal 1 ayat (16) UUK).

Perselisihan Hubungan Industrial adalah: "Perbedaan pendapat yang mengakibatkan pertentangan antara pengusaha atau gabungan pengusaha dengan pekerja/buruh atau serikat pekerja/serikat buruh karena adanya perselisihan mengenai hak, perselisihan kepentingan, perselisihan pemutusan hubungan kerja dan perselisihan antar serikat pekerja/serikat buruh dalam satu perusahaan (Vide Pasal 1 ayat (1) Undang-Undang Nomor 2 Tahun 2004 tentang Penyelesaian Perselisihan Hubungan Industrial, selanjutnya disingkat UU 2/2004 PPHI)". Pengusaha adalah : "Orang perseorangan, persekutuan, atau badan hukum yang menjalankan suatu perusahaan milik sendiri. Orang perseorangan, persekutuan, atau badan hukum yang secara berdiri sendiri menjalankan perusahaan bukan miliknya. Orang perseorangan, persekutuan, atau badan hukum yang berada di Indonesia mewakili perusahaan sebagaimana dipaparkan di atas yang berkedudukan di luar wilayah Indonesia (Vide Pasal 1 ayat (2) huruf $a, b, c$ Permenakertrans RI 32/2008)".

Menurut Pasal 1 ayat (3) huruf a dan b Permenakertrans RI 32/2008, Perusahaan adalah :"Setiap bentuk usaha yang berbadan hukum atau tidak, milik orang perseorangan, milik persekutuan, atau milik badan hukum, baik milik swasta maupun milik negara yang mempekerjakan pekerja/buruh dengan membayar upah atau imbalan dalam bentuk lain. Usaha-usaha sosial dan usaha-usaha lain yang mempunyai pengurus dan mempekerjakan orang lain dengan upah atau imbalan dalam bentuk lain (Vide Pasal 1 ayat (2) huruf a, b, c Permenakertrans RI 32/2008)".

Pekerja/buruh adalah " setiap orang yang bekerja dengan menerima upah atau imbalan dalam bentuk lain". Serikat pekerja/serikat buruh, adalah:"Organisasi yang dibentuk dari, oleh, dan untuk pekerja/buruh baik di perusahaan maupun di luar perusahaan, yang bersifat bebas, terbuka, mandiri, demokratis, dan bertanggung jawab guna memperjuangkan, membela serta melindungi hak dan kepentingan pekerja/buruh, serta meningkatkan kesejahteraan pekerja/buruh dan keluarganya (Vide Pasal 1 ayat (4) dan ayat (5) Permenakertrans RI 32/2008)". Berdasarkan uraikan maka pelaksana melakukan sosialisasi mengenai tujuan, fungsi dan tugas LKS Bipartit, agar dapat mencegah terjadinya perselisihan 
hubungan industrial dalam suatu perusahaan khususnya di PT Papyrus Sakti Paper Mill serta membentuk LKS Bipartit dalam suatu perusahaan.

\section{B. METODE}

Metode yang digunakan dalam soisalisasi ini adalah dengan memberikan penyuluhan kepada para seluruh Divisi/Bagian Personalia dan Urusan Umum (P\&GA); Divisi/Bagian Purchasing; Divisi/Bagian Planing Produc Inventory Control (PPIC); Divisi/Bagian Pemantauan Pengelola Lingkungan (PPL); Divisi/Bagian Acounting; dan Divisi/Bagian Electronic Data Processing (EDP), yang berlokasikan di PT Papyrus Sakti Paper Mill, Jalan Raya Banjaran Km 16,2 Kabupaten Bandung, Jawa Barat Indonesia, Kode Pos 40379. dilaksanakan pada bulan September 2021.

\section{HASIL ATAU PEMBAHASAN}

Tujuan LKS Bipartit adalah menciptakan hubungan industrial yang harmonis, dinamis, dan berkeadilan di perusahaan dan berfungsi sebagai forum komunikasi dan konsultasi antara pengusaha dengan wakil serikat pekeria/serikat buruh dan/atau wakil pekerja/buruh dalam rangka pengembangan hubungan industrial untuk kelangsungan hidup, pertumbuhan, dan perkembangan perusahaan, termasuk kesejahteraan pekerja/buruh dan mencegah terjadinya perselisihan hubungan industrial, untuk melaksanakan fungsinya tersebut LKS Bipartit bertugas : Melakukan pertemuan secara periodik dan/atau sewaktu-waktu apabila diperlukan, mengkomunikasikan kebijakan pengusaha dan aspirasi pekerja/buruh (antara lain dalam rangka mencegah terjadinya perselisihan hubungan industrial: penulis) di perusahaan dan menyampaikan saran, pertimbangan, dan pendapat kepada pengusaha, pekerja/buruh dan/atau serikat pekerja/serikat buruh dalam rangka penetapan dan pelaksanaan kebijakan perusahaan lainnya (Utami, 2013; Zamhari, 2020) (Vide Pasal 2, Pasal 3 dan Pasal 4 huruf $a, b, c$ Permenakertrans RI 32/2008). Tujuan, Fungsi dan Tugas LKS Bipartit sesuai dengan Asas, Tujuan, dan Sifat Hukum Ketenagakerjaan

Asas Hukum Ketenagakerjaan dan Asas LKS Bipartit "Pembangunan ketenagakerjaan berlandaskan Pancasila dan Undang-Undang Dasar Republik Indonesia Tahun 1945 selanjutnya disingkat UUD 1945" (Vide Pasal 2 UUK). "Pembangunan ketenagakerjaan dilaksanakan dalam rangka pembangunan Indonesia seutuhnya. Oleh sebab itu pembangunan ketenagakerjaan dilaksanakan untuk mewujudkan manusia dan masyarakat Indonesia yang sejahtera, adil, makmur dan merata baik materiil maupun spritual" (Vide penjelasan pasal 2 UUK)".

Asas pembangunan ketenagakerjaan pada dasarnya sesuai dengan asas pembangunan nasional, khususnya asas demokrasi, adil, dan merata (Dewi et al., n.d.). Hal ini dalakukan karena pembangunan ketenagakerjaan menyangkut multidimensi dan terkait dengan berbagai pihak, yaitu antara pemerintah, pengusaha, dan pekerja/buruh. Oleh karena itu pembangunan ketenagakerjaan dilakukan secara terpadu dalam bentuk kerjasama yang saling mendukung sehingga hukum ketenagakerjaan adalah asas keterpaduan melalui koordinasi fungsional lintas sektoral pusat dan daerah (Khakim, 2009).Pembangunan (development) mengandung pengertian: "Suatu proses yang menyebabkan sesuatu dapat tumbuh (growth), atau menjadi lebih matang atau dewasa, lebih maju, lebih terorganisir, arti literal ini bahwa pertumbuhan menjadi karakteristik lebih menonjol dalam proses pembangunan, yaitu pertumbuhan, pemerataan, keadilan (equity) dan kualitas hidup" (Huda, 2017). 
Mengacu kepada asas pembangunan ketenagakerjaan dan pengertian pembangunan sebagaimana sebagaimana dipaparkan di atas, asas dari LKS Bipartit adalah Pancasila dan UUD 1945 mewujudkan kesejahteraan, keadilan, kemakmur secara merata baik materiil maupun spritual para pihak dalam hubungan industrial, yaitu terjadinya pemerataan (equity) dan kualitas hidup dalam suatu hubungan industrial. Asas LKS Bipartit pada dasarnya sesuai dengan asas pembangunan ketenagakerjaan dan pembangunan nasional sebagaimana dipaparkan di atas, khususnya asas pembangunan demokrasi, adil dan merata. Hal ini dilakukan karena pembangunan LKS Bipartit menyangkut multidimensi dan terkait dengan berbagai pihak, yaitu pihak pemerintah, pihak pengusaha, pihak pekerja/buruh, oleh karena itu pembangunan LKS Bipartit dilakukan secara terpadu dalam bentuk Kerjasama yang saling mendukung sehingga asas-asas yang melandasi LKS Bipartit, adalah asas keterpaduan melalui koordinasi semua pihak dalam hubungan industrial.

Tujuan Hukum Ketenagakerjaan dan LKS Bipartit, menurut Manulang, tujuan hukum ketenagakerjaan, adalah: Untuk mencapai/melaksanakan keadilan sosial dalam bidang ketenagakerjaan; Untuk melindungi tenaga kerja terhadap kekuasaan yang tidak terbatas dari pengusaha (Khakim, 2009).

Huruf a lebih menunjukan, bahwa hukum ketenagakerjaan harus menjaga ketertiban, keamanan, dan keadilan bagi pihak-pihak yang terkait dalam proses produksi, untuk mencapai ketenangan bekerja dan kelangsungan berusaha. Adapun huruf $b$ dilatarbelakangi adanya pengalaman selama ini yang kerap kali terjadi kesewenangan-wenangan pengusaha terhadap pekerja/buruh. Untuk itu diperlukan perlindungan secara komprehensif dan kongkret dari pemerintah (Khakim, 2009). Menurut Pasal 4 UUK tujuan ketenagakerjaan, adalah: Memberdayakan dan mendayagunakan tenaga kerja secara optimal dan manusiawi; Mewujudkan pemerataan kesempatan kerja dan penyediaan tenaga kerja yang sesuai dengan kebutuhan pembangunan nasional dan daerah; Memberikan perlindungan kepada tenaga kerja dalam mewujudkan kesejahteraan; dan Meningkatkan kesejahteraan tenaga kerja dan keluarganya. Pemberdayaan dan pendayagunaan tenaga kerja dimaksud untuk dapat memberikan kesempatan kerja seluas-luasnya bagi tenaga kerja Indonesia. Selanjutnya, tenaga kerja Indonesia diharapkan dapat berpartisipasi secara optimal dalam pembangunan nasional, namun dengan tetap menjunjung tinggi nilai-nilai kemanusiaan. Dengan demikian, tujuan pembangunan ketenagakerjaan, adalah menjadikan tenaga kerja Indonesia sebagai subjek pembangunan, bukan sebagai objek pembangunan (Khakim, 2009). Pemberdayaan dan pendayagunaan dapat dilakukan melalui pengembangan sumber daya manusia (SDM) dari pekerja/buruh.

Pengembangan SDM (pekerja/buruh: penulis) didasari pada sebuah filosofi yaitu manusia (pekerja/buruh: penulis) yang disiplin, professional, visioner. Pengembangan SDM (pekerja/buruh: penulis) tersebut dititik beratkan pada peningkatan skill, knowledge dan attitude yang diimplementasinya dilakukan melalui pelaksanaan program pelatihan yang bersifat teknis, manajerial, dan kepemimpinan, on job training, penugasan (mutasi, rotasi) dan promosi jabatan. Melalui program-program tersebut diharapkan seluruh pegawai (pekerja/buruh: penulis) mampu menetapkan tujuan, sasaran, proses kegiatan dan tolak ukur unjuk kerjanya masing-masing sehingga menghasilkan pekerjaan yang lebih efisien, efektif dan produktif (Priansah, 2018). Sehingga tercipta keuntungan perusahaan yang berkorelasi dengan kesejahteraan pekerja/buruh dan keluarganya. 
Pemberdayaan dan pendayagunaan tenaga kerja dan/atau pengembangan SDM sebagaimana dipaparkan di atas, adalah sesuai tujuan LKS Bipartit adalah menciptakan hubungan industrial yang harmonis, dinamis, dan berkeadilan di perusahaan dan memberikan kesempatan kerja seluas-luasnya bagi pekerja/buruh Indonesia untuk dapat berpartisipasi secara optimal dalam pembangunan nasiona (Priansah, 2018), dengan tetap menjunjung tinggi nilai-nilai kemanusiaan, menjadikan pekerja/buruh sebagai subjek pembangunan, bukan sebagai objek pembangunan yaitu melalui LKS Bipartit pekerja/buruh dan/atau wakil pekerja/buruh dapat berkomunikasi dan berkonsultasi dengan pengusaha secara sejajar duduk bersama dalam rangka pengembangan hubungan industrial untuk kelangsungan hidup, pertumbuhan, dan perkembangan perusahaan, termasuk kesejahteraan pekerja/buruh dan keluarganya, sehingga LKS Bipartit dapat digunakan sebagai sarana ntuk mencapai/melaksanakan keadilan sosial bagi semua pihak dalam hubungan industrial dan untuk melindungi pekerja/buruh terhadap kekuasaan yang tidak terbatas dari pengusaha, memberdayakan dan mendayagunakan semua pihak dalam hubungan industrial (terutama pekerja/buruh) secara optimal dan manusiawi, mewujudkan pemerataan kesempatan kerja dan penyediaan pekerja/buruh sesuai dengan kebutuhan pembangunan nasional dan daerah. memberikan perlindungan kepada pekerja/buruh dan keluarganya dalam mewujudkan kesejahteraan, meningkatkan kesejahteraan pekerja/buruh dan keluarganya.

Fungsi LKS Bipartit sesuai dengan fungsi hukum, yaitu sebagai standard of conduct, (Dhamayanti, 2021) yakni sandaran atau ukuran tingkah laku yang harus ditaati oleh setiap orang dalam bertindak dalam melakukan hubungan satu dengan yang lain, sebagai as a tool of social of engeneering, yaitu sebagai sarana atau alat untuk mengubah masyarakat kearah yang lebih baik secara pribadi maupun dalam kehidupan masyarakat. Sebagai as a tool of social of control, yaitu sebagai alat untuk mengontrol tingkah laku dan perbuatan manusia, agar mereka tidak melakukan perbuatan yang melawan norma hukum, agama, susila. Sebagai as a facility on human interaction, yaitu hukum berfungsi tidak hanya untuk menciptakan ketertiban, tetapi juga menciptakan perubahan masyarakat dengan cara memperlancar proses interaksi sosial dan diharapkan menjadi pendorong untuk menimbulkan perubahan dalam kehidupan masyarakat (Dhamayanti, 2021). Fungsi LKS Bipartit sebagai standard of conduct, yakni sandaran atau ukuran tingkah laku yang harus ditaati oleh semua pihak dalam hubungan industrial (pengusaha, pekerja/buruh, pemerintah) dalam hubungan industrial dan/atau dalam melakukan hubungan industrial antara pekerja/buruh, pengusaha, pemerintah. Fungsi LKS Bipartit sebagai as a tool of social of engeneering ", yaitu LKS Bipartit merupakan sarana atau alat untuk mengubah semua pihak dalam hubungan industral kearah yang lebih baik secara pribadi pengusaha dan pribadi pekerja/buruh maupun dalam hubungan industrial demi menciptakan hubungan industrial yang harmonis, dinamis, dan berkeadilan di perusahaan. Fungsi LKS Bipartit sebagai as a tool of social of control, yaitu LKS Bipartit sebagai alat untuk mengontrol tingkah laku dan perbuatan semua pihak dalam hubungan industrial, agar tidak melakukan perbuatan yang melawan norma hukum baik hukum ketenagakerjaan maupun hukum hubungan industrial atau norma agama dan norma kesusilaan. Fungsi LKS Bipartit sebagai as a facility on human interaction, yaitu LKS Bipartit tidak hanya untuk menciptakan ketertiban, tetapi juga menciptakan perubahan semua pihak dalam hubungan industrial dengan cara memperlancar proses interaksi sosial dalam hubungan industrial dan diharapkan menjadi pendorong untuk menimbulkan perubahan dalam kehidupan 
dalam hubungan industrial menuju hubungan industrial yang harmonis, dinamis, dan berkeadilan dalam perusahaan. Fungsi LKS Bipartit sebagai standard of conduct, sebagai as a tool of social of engeneering, sebagai as a tool of social of control, sebagai as a facility on human interaction akan berjalan dengan baik apabila LKS Bipartit betul-betul dilaksanakan semua pihak dalam hubungan industrial (terutama pengusaha) sebagai forum komunikasi dan konsultasi antara pengusaha dengan wakil serikat pekerja/serikat buruh dan/atau wakil pekerja/buruh dalam rangka pengembangan hubungan industrial untuk kelangsungan hidup, pertumbuhan, dan perkembangan perusahaan, termasuk kesejahteraan pekerja/buruh keluarganya.

LKS Bipartit dan Hubungan Industrial Harmonis (Industrial Peace), terciptanya ketenangan kerja dan berusaha, suatu kodisi dinamis di dalam hubungan kerja di perusahaan di mana terdapat 3 (tiga) unsur penting, yaitu: Hak dan kewajiban terjamin dilaksanakan; Apabila timbul perselisihan (industrial: penulis) dapat diselesaikan secara internal;dan Mogok dan penutupan perusahaan (lock-out) tidak perlu digunakan untuk memaksakan kehendak, karena perselisihan (industrial: penulis) yang terjadi telah dapat diselesaikan dengan baik (Suwarto, 2003).

Pengertian hak dan kewajiban terjamin dilaksanakan, sebagai tersebut dalam huruf a di atas Suwarto menyebutnya kondisi kerja (working condition) yaitu merupakan tingkat keadaan ketenagakerjaan yang dilihat dari pengaturan hak dan kewajiban antara pekerja/buruh dan pengusaha atau pimpinan perusahaan. Kondisi kerja menurut Suwarto dapat dibedakan menjadi 2 (dua) garis besar ialah norma kerja (labour legislation) dan syarat kerja (terms of employment) (Suwarto, 2003).

Norma keria (labour legislation), pada dasarnya adalah pengaturan hak dan kewajiban bagi pekerja/buruh dan pengusaha yang tertuang dalam peraturan perundang-undangan, yang bersifat imperatif dan wajib, harus dilaksanakan, mengikat semua perusahaan, bersifat makro minimal. Makro dalam arti mengikat perusahaan tanpa kecuali baik tempat, ukuran, jenis usaha, sifat badan hukum dan lain sebagainya (Zulkarnaen, 2018). Minimal dalam arti bahwa dalam praktek mengenai hal-hal yang diatur dapat dilaksanakan lebih baik atau lebih besar tergantung kemampuan dan kemauan perusahaan secara individual (Suwarto, 2003).

Syarat kerja (terms of employment), adalah pengaturan hak dan kewajiban pekerja/buruh dan pengusaha berbagai aspek hubungan kerja yang belum diatur atau tidak diatur oleh peraturan perundang-undangan (norma kerja), pengaturan ini bersifat mikro-kondisional. Mikro dalam arti diatur hanya untuk perusahaan tertentu secara individual, kondisional dalam arti pengaturan disesuaikan dengan kondisi atau kemampuan perusahaan yang bersangkutan. Bentuk syarat kerja adalah Perjanjian Kerja, Peraturan Perusahaan, Perjanjian Kerja Bersama (Suwarto, 2003).

LKS Bipartit dapat mewujudkan hubungan industrial harmonis (industrial peace) sebagaimana dipaparkan di atas, yaitu apabila LKS Bipartit betul-betul berfungsi sebagai forum komunikasi dan konsultasi antara pengusaha dengan wakil serikat pekerja/serikat buruh dan/atau wakil pekerja/buruh sehingga hak dan kewajiban pekerja/buruh dan pengusaha terjamin dilaksanakan, melalui LKS Bipartit dapat mencegah terjadinya perselisihan hubungan industrial, kalaupun terjadi perselisihan industrial dapat diselesaikan secara internal sehingga mogok atau penutupan perusahaan (lock out) tidak perlu digunakan untuk memaksakan kehendak. 
LKS Bipartit, Hubungan Industrial Harmonis (Industrial Peace), Asas Hukum Ketenagakerjaan. Asas LKS Bipartit sejalan dengan asas pembangunan ketenagakerjaan berlandaskan Pancasila dan UUD RI Tahun 1945." Pembangunan ketenagakerjaan dilaksanakan dalam rangka pembangunan Indonesia seutuhnya. Oleh sebab itu pembangunan ketenagakerjaan dilaksanakan untuk mewujudkan manusia dan masyarakat Indonesia yang sejahtera, adil, makmur dan merata baik materiil maupun spritual" (Vide penjelasan pasal 2 UUK)".

Asas pembangunan ketenagakerjaan sebagaimana dipaparkan di atas, sejalan dengan fungsi LKS, yaitu sebagai forum komunikasi dan konsultasi antara pengusaha dengan wakil serikat pekerja/serikat buruh dan/atau wakil pekerja/buruh sehingga hak dan kewajiban pekerja/buruh dan pengusaha baik yang bersifat norma kerja ((labour legislation) dan syarat kerja (terms of employment) terjamin dilaksanakan, hal ini merupakan salah satu sarana untuk mewujudkan manusia dan masyarakat Indonesia yang sejahtera, adil, makmur dan merata baik materiil maupun spiritual.

Asas pembangunan ketenagakerjaan pada dasarnya sesuai dengan asas pembangunan nasional, khususnya asas demokrasi, adil, dan merata. Hal ini dalakukan karena pembangunan ketenagakerjaan menyangkut multidimensi dan terkait dengan berbagai pihak, yaitu antara pemerintah, pengusaha, dan pekerja/buruh. Oleh karena itu pembangunan ketenagakerjaan harus dilakukan secara terpadu dalam bentuk kerjasama yang saling mendukung, sehingga (salah satu asas: penulis) hukum ketenagakerjaan adalah asas keterpaduan melalui koordinasi fungsional lintas sektoral pusat dan daerah (Khakim, 2009)

Berdasarkan paparkan di atas, asas LKS Bipartit harus sesuai dengan asas pembangunan ketenagakerjaan dan asas pembangunan nasional, yaitu asas demokrasi, asas keadilan yang merata, asas multidimensi, asas keterkaitan dengan berbagai pihak yang terlibat dalam hubungan industrial, asas keterpaduan, asas kerjasama saling ketergantungan, asas saling mendukung, asas demokratis, asas keadilan, asas merata untuk semua pihak dalam hubungan industrial (pengusaha, pekerja/buruh dan pemerintah), salah satu tujuan dari semua asas-asas LKS Bipartit tersebut di atas, adalah mewujudkan hubungan industrial harmonis (industrial peace).

LKS Bipartit, Hubungan Industrial Harmonis (Industrial Peace), Tujuan Hukum Ketenagakerjaan. Menurut Manulang tujuan Hukum Ketenagakerjaan, adalah: Mencapai/melaksanakan keadilan sosial dalam bidang ketenagakerjaan; dan Melindungi tenaga kerja terhadap kekuasaan yang tidak terbatas dari pengusaha (Khakim, 2009).

Huruf a lebih menunjukan, bahwa hukum ketenagakerjaan harus menjaga ketertiban, keamanan, dan keadilan bagi pihak-pihak yang terkait dalam proses produksi, untuk mencapai ketenangan bekerja dan kelangsungan berusaha. Adapun huruf $b$ dilatarbelakangi adanya pengalaman selama ini yang kerap kali terjadi kesewenangan-wenangan pengusaha terhadap pekerja/buruh. Untuk itu diperlukan perlindungan secacara komprehensif dan kongkret dari pemerintah (Khakim, 2009).

Tujuan pembangunan ketenagakerjaan menurut Pasal 4 Undang-Undang Ketenagakerjaan Nomor 13 Tahun 2003 tentang Ketenagakerjaan (UUK), adalah: Memberdayakan dan mendayagunakan tenaga kerja secara optimal dan manusiawi; Mewujudkan pemerataan kesempatan kerja dan penyediaan tenaga kerja yang sesuai dengan kebutuhan pembangunan nasional dan daerah; Memberikan perlindungan kepada tenaga kerja dalam mewujudkan kesejahteraan; dan Meningkatkan kesejahteraan tenaga kerja dan keluarganya. 
Pemberdayaan dan pendayagunaan tenaga kerja dimaksud untuk dapat memberikan kesempatan kerja seluas-luasnya bagi tenaga kerja Indonesia. Selanjutnya, tenaga kerja Indonesia diharapkan dapat berpartisipasi secara optimal dalam pembangunan nasional, namun dengan tetap menjunjung tinggi nilai-nilai kemanusiaan. Dengan demikian, tujuan pembangunan ketenagakerjaan, adalah menjadikan tenaga kerja Indonesia sebagai subjek pembangunan, bukan sebagai objek pembangunan (Khakim, 2009).

LKS Bipartit Mencegah Terjadinya Perselisihan Hubungan Industrial dengan tercapainya asas dan tujuan LKS Bipartit sebagaimana dipaparkan di atas, keberadaan sarana LKS Bipartit dapat mencegah terjadinya perselisihan hubungan indusrial. Menurut Pasal 1 ayat (1) Undang-Undang Nomor 2 Tahun 2004 tentang Penyelesaian Perselisihan Hubungan Industrial (UU 2/2004 PPHI), Perselisihan Hubungan Industrial adalah perbedaan pendapat yang mengakibatkan pertentangan antara pengusaha atau gabungan pengusaha dengan pekerja/buruh atau serikat pekerja/serikat buruh karena adanya perselisihan mengenai hak, perselisihan kepentingan, perselisihan pemutusan hubungan kerja dan perselisihan antar serikat pekerja/serikat buruh dalam satu perusahaan.

Perselisihan hak adalah perselisihan yang timbul karena tidak dipenuhinya hak (norma kerja: penulis), akibat adanya perbedaan pelaksanaan atau penafsiran terhadap ketentuan peraturan perundang-undangan, perjaniian kerja, peraturan perusahaan, atau perjanjian kerja Bersama (Vide Pasal 1 ayat (2) UU 2/2004 PPHI).

Perselisihan kepentingan adalah perselisihan yang timbul dalam hubungan kerja karena tidak adanya kesesuaian pendapat mengenai pembuatan, dan/atau perubahan syaratsyarat kerja yang ditetapkan dalam perjanjian kerja, atau peraturan perusahaan, atau perjanjian kerja Bersama (Vide Pasal 1 ayat (3) UU 2/2004 PPHI).

Perselisihan pemutusan hubungan kerja adalah perselisihan yang timbul karena tidak adanya kesesuaian pendapat mengenai pengakhiran hubungan kerja yang dilakukan oleh salah satu pihak (Vide Pasal 1 ayat (4) UU 2/2004 PPHI).

Perselisihan antar serikat pekerja/serikat buruh adalah perselisihan antara serikat pekerja/serikat buruh dengan serikat pekerja/serikat buruh lain hanya dalam satu perusahaan, karena tidak adanya persesuaian paham mengenai keanggotaan pelaksanaan hak, dan kewajiban keserikatpekerjaan (Vide Pasal 1 ayat (5) UU 2/2004 PPHI).

Berdasarkan paparan di atas, tujuan LKS Bipartit adalah untuk mencegah terjadinya perselisihan hubungan industrial demi mewujudkan hubungan industrial harmonis (industrial peace), yaitu terjamin dan terlaksananya hak dan kewajiban pekerja/buruh dan pengusaha minimal hak dan kewajiban bersifat norma kerja (labour legislation) maximal berupa syarat keria (terms of employment), dengan terjaminnya hak dan kewajiban bersifat norma kerja (labour legislation) dan syarat keria (terms of employment), maka akan mencegah terjadinya perselisihan hubungan industrial baik berupa perselisihan hak, perselisihan kepentingan, perselisihan pemutusan hubungan keria.

Hubungan industrial harmonis (industrial peace) sebagaimana dipaparkan di atas akan terwujud apabila fungsi LKS Bipartit sesuai Pasal 2, Pasal 3 dan Pasal 4 huruf a, b, c Permenakertrans RI 32/2008 teraplikasi dengan baik, yaitu LKS Bipartit bertugas : Melakukan pertemuan secara periodik dan/atau sewaktuwaktu apabila diperlukan, mengkomunikasikan kebijakan pengusaha dan aspirasi pekerja/buruh dalam rangka mencegah terjadinya permasalahan hubungan 
industrial (perselisihan hubungan industrial: penulis) di perusahaan dan menyampaikan saran, pertimbangan, dan pendapat kepada pengusaha, pekerja/buruh dan/atau serikat pekerja/serikat buruh dalam rangka penetapan dan pelaksanaan kebijakan perusahaan dalam upaya mencegah perusahaan menetapkan dan melaksanakan kebijakan yang berpotensi terjadinya perselisihan hubungan industrial sebagaimana ditetapkan di atas.

Fungsi lain dari LKS Bipartit adalah menyelesaikan perselisihan hubungan industrial secara musyawarah (Bipartit), Perundingan bipartit adalah perundingan antara pekerja/buruh atau serikat pekerja/serikat buruh dengan pengusaha untuk menyelesaikan perselisihan hubungan industrial (Vide Pasal 1 ayat (10) UU 2/2004 PPHI)

Perselisihan hubungan industrial wajib diupayakan penyelesaiannya terlebih dahulu melalui perundingan bipartit secara musyawarah untuk mencapai mufakat. Penyelesaian perselisihan melalui bipartit harus diselesaikan paling lama 30 (tiga puluh) hari kerja sejak tanggal dimulainya perundingan Apabila dalam jangka waktu 30 (tiga puluh) hari sebagaimana dimaksud di atas salah satu pihak menolak untuk berunding atau telah dilakukan perundingan tetapi tidak mencapai kesepakatan, maka perundingan bipartit dianggap gagal. Dalam hal perundingan bipartit gagal maka salah satu atau kedua belah pihak mencatatkan perselisihannya kepada instansi yang bertanggung jawab di bidang ketenagakerjaan setempat dengan melampirkan bukti bahwa upaya-upaya penyelesaian melalui perundingan bipartit telah dilakukan (Vide Pasal 3 ayat (1), ayat (2), ayat (3), Pasal 4 ayat (1) UU 2/2004 PPHI).

Apabila bukti-bukti perundingan bipartit tidak dilampirkan, maka instansi yang bertanggung jawab di bidang ketenagakerjaan mengembalikan berkas untuk dilengkapi paling lambat dalam waktu 7 (tujuh) hari kerja terhitung sejak tanggal diterimanya pengembalian berkas. (Setelah menerima pencatatan dari salah satu atau para pihak, instansi yang bertanggung jawab di bidang ketenagakerjaan setempat wajib menawarkan kepada para pihak untuk menyepakati memilih penyelesaian melalui konsiliasi atau melalui arbitrase. Dalam hal para pihak tidak menetapkan pilihan penyelesaian melalui konsiliasi atau arbitrase dalam waktu 7 (tujuh) hari kerja, maka instansi yang bertanggung jawab di bidang ketenagakerjaan melimpahkan penyelesaian perselisihan kepada mediator (Vide Pasal 4 ayat (2), ayat (3), ayat (4) UU 2/2004 PPHI).

Penyelesaian melalui konsiliasi dilakukan untuk penyelesaian perselisihan kepentingan, perselisihan pemutusan hubungan kerja, atau perselisihan antar serikat pekerja/serikat buruh dan Penyelesaian melalui arbitrase dilakukan untuk penyelesaian perselisihan kepentingan atau perselisihan antar serikat pekerja/serikat buruh. Dalam hal penyelesaian melalui konsiliasi atau mediasi tidak mencapai kesepakatan, maka salah satu pihak dapat mengajukan gugatan kepada Pengadilan Hubungan Industrial (Vide Pasal 4 ayat (2), ayat (4), ayat (5), ayat (6), Pasal 5 UU 2/2004 PPHI).

Tata Cara Pembentukan LKS Bipartit Menurut Pasal $5 \mathrm{~s} / \mathrm{d}$ Pasal Permenakertrans RI 32/2008. Kepengurusan LKS Bipartit di atur Dalam Pasal 10 s/d 13 Permenakertrans RI 32/2008. Tata Kerja LKS Bipartit di atur Dalam Pasal 14 Permenakertrans RI 32/2008. Pembinaan LKS Bipartit Di atur Dalam Pasal 15 Permenakertrans RI 32/2008. Sedangkan Pembiayaan dan Pelaporan Kegiatan LKS Bipartit Di atur Dalam Pasal 16 s/d Pasal 17 Permenakertrans RI 32/2008, yang mana instansi yang bertanggung jawab di bidang ketenagakerjaan provinsi secara berkala setiap 6 (enam) bulan sekali melaporkan kepada Menteri melalui 
Direktur Jenderal Pembinaan Hubungan Industrial dan Jaminan Sosial Tenaga Keria.

\section{PENUTUP}

Pelaksanaan kegiatan pengabdian masyarakat oleh lembaga penelitian dan pengembangan masyarakat (LPPM) Universitas Suryakancana yang dilakukan oleh Ahmad Hunaeni Zulkarnaen berjalan dengan lancar dan mendapat sambutan hangat dari tempat pelaksanaan kegiatan dan para pekerja/karyawan PT Papyrus Sakti Mill ini yaitu \pm 24 (kurang lebih Dua Puluh Empat) pekerja/karyawan PT Papyrus Sakti Mill sebagaimana tersebut di atas. Pelaksanaan pengabdian masyarakat ini membuat semua pihak dalam hubungan industrial (pengusaha/pimpinan perusahaan, pekerja/karyawan) di PT Papyrus Sakti Pape Mill lebih memahami terutama mengenai tujuan, fungsi, tugas dan cara membentuk LKS Bipartit hubungannya dalam mencegah terjadinya perselisihan hubungan industrial di PT Papyrus Sakti Paper Mill yaitu LKS Bipartit dapat mencegah terjadinya perselisihan hubungan industrial dan apabila terjadi perselisihan melalui sarana LKS Bipartit dapat diselesaikan secara musyawarah (bipartit) sehingga mogok atau penutupan perusahaan (lock out) tidak pernah digunakan untuk memaksakan kehendak, pada akhirnya dengan diaplikasikannya sarana LKS Bipartit terjadi peningkatan produktivitas perusahaan yang berkorelasi dengan kesejahteraan pekerja/karyawan dan keluarga pekeria/karyawan PT Papyrus Sakti Paper Mill.

\section{E. DAFTAR PUSTAKA}

Dewi, N. K. A. T., Darmadha, I. N., \& Pujawan, I. M. (n.d.). Penerapan Asas Pembangunan Ketenagakerjaan Terkait Hak Jaminan Sosial Pekerja Pada PT. Sinar Dewata Di Kabupaten Jembrana. E-Jurnal Universitas Udayana, 1-13.

Dhamayanti, S. K. (2021). Analisis implementasi tanggung jawab sosial berbasis stakeholder pada perusahaan perkebunan kelapa sawit. Blogchain: Jurnal Bisnis, Logistik Dan Supply Chain, 1(2), 86-96.

Huda, N. (2017). Ekonomi Pembangunan Islam. Prenada Media.

Khakim, A. (2009). Dasar-Dasar Hukum Ketenagakerjaan Indonesia. Citra Aditya Bakti.

Priansah, D. J. (2018). Perencanaan dan Pengembangan SDM. Alfabeta.

Suwarto. (2003). Hubungan Industrial Dalam Praktek. Asosiasi Hubungan Industrial Indonesia.

Utami, K. T. (2013). Peran Serikat Pekerja dalam Penyelesaian Perselisihan Pemutusan Hubungan Kerja. Jurnal Wawasan Hukum, 28(1), 675-686. http://ejournal.sthb.ac.id/index.php/iwy/article/view/63/45

Zamhari, M. (2020). Analisis Efektifitas Lembaga Keria Sama Bipartit dalam Pencegahan Perselisihan Hubungan Industrial di Perusahaan. Jurnal Widyaiswara Indonesia, 1(1), 1-8. http://ejournal.iwi.or.id/ojs/index.php/iwi/article/view/17/9

Zulkarnaen, A. H. (2018). Konfigurasi Politik Dan Karakter Hukum Dalam Perumusan Perjanjian Kerja Perorangan Dan Perjanjian Kerja Bersama. Jurnal Hukum Mimbar Justitia, 4(1), 89-111. https://doi.org/10.35194/ihmi.v4i1.369 